\title{
RELIGIOUS PLURALISM (PERSPECTIVE OF ISLAMIC NORMATIVITY AND HISTORY)
}

\author{
Ekawati Hamzah \\ Department of Akhwalus Syakhsiyyah, Institut Agama Islam (IAI) As'adiyah Sengkang \\ Veteran Street No. 46, Wajo, Indonesia. 90914 \\ Email: hamzahekawati@gmail.com
}

\begin{abstract}
This paper discusses "Normative and Historical Perspective Religious Pluralism, which includes two main problems, namely: First, how is religious pluralism in a historical perspective. Second, how is religious pluralism with a normative perspective. Religious pluralism in the perspective of revelation (Normative) is not only part of a humanitarian task but also a dimension of the Muslim's level, devotion and a religious duty which is the value of worship in the sight of Allah SWT. Whereas historically, the religious attitude in the midst of a plural society was exemplified by the Prophet in the early days of Islam, so that in its development it became the religion that most respected the values of plurality. Therefore, in its development, Muslims do not need to feel a dilemma if in their life they have to intersect with other religions, instead they must be used as life partners in facing the benefit of the people.
\end{abstract}

Keywords: historical, normative, pluralism, religion

\begin{abstract}
Abstrak: Tulisan ini membahas tentang "Pluralisme Agama Perspektif Normatif dan Historis, yang mencakup dua permasalahan pokok yaitu: Pertama, bagaimana pluralisme agama perspektif historis; Kedua, bagaimana pluralisme agama perspektif normatif. Pluralisme agama perspektif wahyu (normatif) tidak saja merupakan bagian tugas kemanusiaan tetapi juga merupakan dimensi dari tingkat kemusliman, ketakwaan dan merupakan tugas agama yang menjadi nilai ibadah di sisi Allah SWT. Sedangkan secara historis, sikap keberagamaan di tengah-tengah masyarakat yang plural sudah dicontohkan oleh Nabi saw. di masa awal Islam, sehingga dalam perkembangannya ia menjadi agama yang paling menghargai nilai-nilai pluralitas. Olehnya itu, dalam perkembangannya kaum muslim tidak perlu merasa dilema apabila dalam kehidupannya harus bersinggungan dengan agama-agama lain, justru harus dijadikan mitra hidup dalam menghadapi kemaslahatan umat.
\end{abstract}

Kata Kunci: agama, historis, normatif, pluralisme

\section{Introduction}

The phenomenon of human religion in the discourse of contemporary religious studies can be approached from various points of view. Religion is no longer seen only from the normative point of the view of His revelation's teaching, although this phenomenon is a characteristic of existing religions, but religion is also approached from an angle closely related to the historical interpretation of religion followers, individual or group of religious teachings which he embraces. The normativity of the teachings of a religion is generally built through an absolute theological and doctrinal approach, while the historicity of human religion is analyzed through historical, philosophical, psychological, sociological, cultural and anthropological approaches (Abdullah, 1999). The typologization of normativity and historicity is still open-ended. There are other possibilities that fall into these two categories.

The relationship between the two approaches always exists in a setting like two sides of a coin that are "inseparable" but firmly "distinguishable" the relationship between the two entities that are united in a complete, unified and solid understanding of the core of religion and morality remains and put forward. In understanding and explaining various religious phenomena it will be obtained when it is clear that it has a referential sacred source in the form of revelation which is basically the authority of God. Instead, a thought has a religious nuance when it is taken from the sacred sources (holy book as doctrine) of that religion (Akkas \& Noer, 2000). However, when the meaning or essence and morality of religion falls into the realm of the historicity of human life, then it cannot be avoided from the shackles of space and time. Because when religion is in the midst of its adherents which then becomes an interpretive and there is an institution, then religion becomes historical, psychological, political, anthropological, and group phenomena (Hidayat, 2002). Like all existing religious traditions, religious precepts must continually undergo development of thought (reinterpreted). The result is a fluctuation of ideas and a divergence in 
time and space. In this way, the relationship between the doctrines of a religion and its historicity will feel more alive, fresher and open ended.

\section{A. Islamic Normative Perspective Religious Pluralism}

Discussion of Islam and the orientation of other social problems cannot be separated from an axiom idea that Islam is the teaching of God with a set of values it carries, values that come from transcendental "something" but it is fully oriented towards things that are concrete for human life to provide basic moral assumptions, motivation and direction for the creation of a civilized and humane and transcendent life (Maarif, 1985). In the study of Islamic studies, that anyone who has an interest in studying Islam in a pure and in-depth manner, both normative Islam and historical Islam, cannot escape the reality of early Islam, namely the Al-Qur'an and the seventh century (Kung, 1998). Al-Qur'an is a descriptive normative reflection through what and how Muslims perceive the world and their lives as well as the important forms to observe in it. And in the 7th (seventh) century AD, that is, an early community from the time of Prophet Muhammad SAW. And furthermore his four caliphs, as a paradigm for any ideal study to which Muslims always refer. It is from here that they form an understanding of their own era (Bellah, 2000).

A religion, whether classified as a revealed religion (Samawi) or not (Ardhi), if we agree with such typologization, cannot be separated from the social influence, situation and its complex origins (Enginerr, 1993). That is how Islam was born and developed to carry the characteristics of the place where it was born. Historically, since its birth, Islam has carried a pluralistic style of teaching. Because, apart from being born and growing in the midst of a multi-ethnic-pluralist social condition, theologically Islam actually carries the ideas of pluralism, including ethnicity, race, color, nation and even religion. If in the holy book it says that God created humans with all the consequences of their varieties so that they know each other, QS. Al Hujurat: 13.

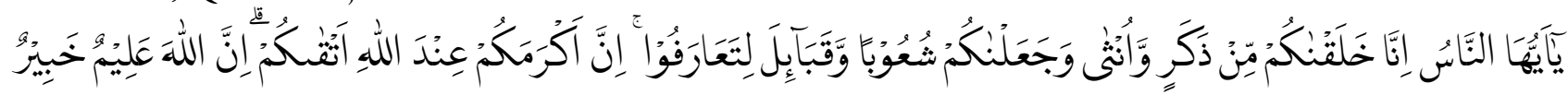

\section{Meaning:}

"O mankind, indeed We have created you from male and female and made you peoples and tribes that you may know one another. Indeed, the most noble of you in the sight of Allah is the most righteous of you. Indeed, Allah is Knowing and Acquainted".

Apart from that, plurality in Islamic teachings is a necessity and the law of God and evidence of His power as determined by the al-Qur'an, QS Ar Ruum: 22.

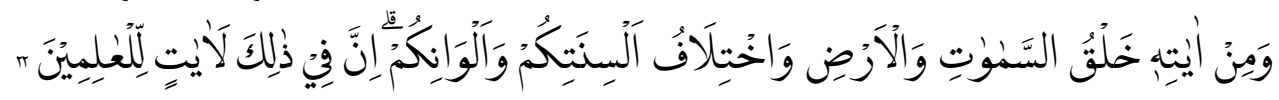

Meaning:

"And of His signs is the creation of the heavens and the earth and the diversity of your languages and your colors. Indeed in that are signs for those of knowledge".

The holy word above actually teaches about the importance of treating the differences and plurality of Islam wisely. Namely to know each other and learn above the differences and plurality, to complement and strengthen mutual understanding and not to see it from the perspective of high and low human beings. Because the level of a person is not determined by the reality of differences and plurality, but by the level of devotion (Asy'Arief, 2002). So this plurality in Islam actually becomes an idea or understanding (pluralism). Namely a value system that views plurality positively and optimistically by accepting it as an undeniable reality, then competing in kindness in that plurality (Akkas \& Noer, 2000). This pluralism is because Islam according to its doctrine carries pluralistic ideas (Ali et al., 1998), the editorial of Surah Al Hujurat verse 13, as written by M. Quraish Shihab, is one of the factors in the emergence and development of pluralism in Islam (Shihab, 1998).

"For every people among you, we give you rules and a clear path. If God wants you to make you one people only, but God wants to test you against his gift to you, then, race in goodness". This quotation from Al-Qur'an surah $\mathrm{Al}$ 
Maidah: 48 can be said to be the core as well as an understanding of the problem of religious pluralism in a normative view of Islam. The above statement departs from the assumption about the reality of this one world, where humans in the world live in social facts divided into various groups, each of which has a different life goal. "For each group has a goal, that's where it directs it" [QS. Al Baqarah (2): 148]. Plurality is indeed a necessity, from each of these groups it is hoped that a real contribution to accept this diversity is expected, tolerate one another by giving freedom and the widest possible opportunity for everyone to live their life according to their respective beliefs. What is needed in a plural society is for each group to compete in a pluralistic life in a healthy and correct way.

Our world is one, but pluralistic, an understanding of this one world demands a more realistic religious view that religious pluralism is a global fact which is both uniqueness and a necessity. It is impossible for this world to be one or single absolutely [QS. Huud (11): 118-119], without any difference elements in it. Because it is precisely unity and togetherness that can be achieved under different circumstances. Unit in diversity, to quote the term Nurcholish Madjid, or agree in disagreement when using the term H. A. Mukti Ali. On the other hand, the scriptures require a society that seems united but their hearts are divided [QS. Al Hasyr (59): 14].

Globalization of information and its influence has spread throughout the world. An expression that should be contemplated in such a world context is that the life of religious people in this transparent world must have the right vision of their religion and other communities with a positive awareness of plurality. Each community should understand and seriously consider the self-awareness of each group and all its differences (Hidayat \& Gaus, 1992). Religious plurality is one of the visions brought by the Qur'an and has been historically translated at a practical level by the Prophet SAW and generally in the early days. Positive religious plurality is sunnatullah, God's provisions that will not change, "wa lan tajida li sunnatullabi Tabdila" [al Ahzab: 62].

The theological basis for that truth can be traced explicitly by referring to the words of God in the Holy Qur'an. That God created humans with various consequences of diversity, gender, race, nation [QS. al Hujurat (49): 13], where plurality is essentially one of the signs of His power [QS. Ar Rum (30): 22] which if he wants a uniform [QS. Huud (11): 118-119], because everything is nothing that is impossible for him [QS. Yaasin (36): 82], but God wants to test all human beings because they always disagree with [QS. Al Maidah (5): 48].

Further research and interpretation of the content and the holy texts of the Qur'an as a whole regarding religious pluralism. Normatively, the Qur'an provides 3 different response models, namely: acknowledging, providing criticism and teaching tolerance of thought.

First, the recognition of the Al-Qur'an for religions other than Islam is one of the foundations of faith in QS Islam [Al Baqarah (2): 4], that having faith in God's revelations before the time of Muhammad SAW's sending is characteristic for people who are devout. This means that the recognition of the religions that receive the revelations is part of the core of faith, even though this recognition is placed within the framework of "religious unity" (An Nuri, 2002). This is because the essence of the teachings that Allah conveyed to the Prophet Muhammad SAW is the same as the core teachings conveyed by Him to all Prophets. His revelations in the form of the holy book Torah, Zabur, Gospel, and Suhuf to the prophet Ibraham AS all come from the same God, so the substance of the messages of the revelations, especially those concerning as far as the principles and fundamental teachings will not conflict with one another. Therefore, in fact, the followers of Allah's religion are a single people (Madjid, 2002).

Second, in addition to the recognition of the Qur'an for the reality of pluralism of religions, Islam also provides criticism and corrections to its predecessor, the Jewish and Christian religions as an effort to call people back to the same truth. Recognition of other religions is not a full confirmation or acknowledgment but, it provides criticism and limits that recognition to elements that are in line with Islamic teachings. Pre-Islamic religions, especially Judaism and Christianity, he admits as antecedents of Islam, where the process of development culminated in the sending of the Prophet Muhammad (An Nuri, 2002). This model of criticism means that however there are differences from the beginning or significant "deviations" - tahrif - and consciously reject the message of the Prophet Muhammad. In this case, one of the reasons for the presence of Islam is to straighten the straight lines of the previous 
religions as well, to straighten and complete religion so that he does not force people to believe in him. Because even God, there is nothing that is impossible for Him, does not impose it, and if he wants, of course, people will be made as one people only, or all have faith in Him [QS. Yunus (10): 99]. With that verse Allah forbids, rebukes and warns Prophet Muhammad SAW when he desires to 'force people to accept and follow his teachings,' and if your Lord wills, surely all the people on Earth have faith entirely. So, do you (want) to force people so that everyone should believe?'

As a result, for the existence of other religions, the teachings of Islam do not deny it at all. Although they are criticized for their existence and teachings, Islam provides a very amazing identity which is explicitly emphasized by the Qur'an that it is people who believe (Muslims), Jews, Christians, Sabi'in whoever they are who believe in God and in the next day and do good deeds, they will get reward from Him, there is no fear and sadness [QS. Al Baqarah (2): 62]. This recognition of religious identity and pluralism is reinforced by the prohibition of Islam from committing insults to the worship of other religions in order to maintain their feelings and race along with them [QS. An Nahl (16): 108-109]. So it can be understood that, in Islamic doctrine, it emphasizes that maintaining an atmosphere of religious freedom and respecting the plurality of religions and other beliefs regardless of their form is not only a necessity of action and a pluralistic community life order, which is certain in that there are elements of difference but more than That is, for a Muslim all of these are religious teachings that contain both divine and human values which are perennial. Such a statement is implicitly stated in the holy book of the Koran which is symbolized in the attitude of having to defend the places of worship which are called the name of God, such as monasteries, churches, synagogues and mosques [Al Hajj (22): 40].

Thus the Qur'an as the last message of God provides a glorious description and clear evidence of the ideas it compiled, namely: the idea of plurality of religions, religious pluraism. The uniqueness and distinctiveness of the Qur'an lies not only in its textuality which explicitly mentions religions other than Islam in it, although indeed it is the only holy book that mentions religions other than those that carry it, but lies in recognition of identity, protection of the home. -homes of worship for Judaism and Christianity as well as Sabi'ah. Even the inclusiveness of historical exclusivity is explicitly stated in the Qur'an [Al Baqarah (2): 62].

The view of Islam which is normative and very positive towards the recognition of pluralism and freedom to embrace this religion naturally fosters a sense of inclusiveness among Muslims in the early days because pluralism and inclusiveism are two entities that are interrelated and inseparable. They do not only respect and allow other religions to exist in existence as they are obliged to do justice to them, do not insult the means of worship and protect houses of worship.

Islamic pluralism in the framework of its historicity is translated into its empirical reality, firstly in the Medina charter by the Prophet for the inhabitants of Medina as a whole and the second is Umar Bin Khattab's mitsaq Aelia for the residents of Yerussaleem after the city was politically controlled by Muslims. The Aelia Charter (Mitsaq Aeliya), a charter agreement made by Umar ibn Khattab when he released Al-Quds (Aelia) from Roman hands signed on 20 Rabiul Awal 15H. The Charter aimed to guarantee the security and safety of various parties in the Jerusalem area which had just been taken over by the Muslim forces and to overcome the turmoil that usually arose in transitional societies, Umar ibn Khattab made the Aelia Charter just like what the Prophet did in the Medina charter. Medina Charter contains the principles of pluralism, a historical document that guarantees freedom of religion with an emphasis on cooperation and aims to maintain mutual security. There is no doubt that the Prophet's brilliant idea in making a joint plate form in a constitution is a logical inspiration from the principle of pluralism in Islam.

The Holy Prophet said, "whoever disturbs the dhimmi (non-Muslim minority) then he has disturbed me". This Prophet's expression shows how much the Prophet's sense of responsibility for the existence and survival of non-Muslims under his political power in all its forms, from security, education and economic factors, for example Muslims and non-Muslims have the same obligation to pay taxes (Al Maududi \& Al Mulk, 1995). Even though in the new city of Medina, the Prophet and the Muslims were the majority ummah with Muslim "domination", a religiously pluralist society did indeed take shape and had become the common consciousness of the first Muslim generation. 
The Medina Charter is a historical description if Islam actually does not recognize totalitarianism and all aspects of coercion, but its accommodative character is so prominent. The Islamic community at that time was not an exclusive plural majority, but it was actually very inclusive, tolerant and understood the reality of religious pluralism in its meaning and practice. With this charter, Islam has ended the exclusivity attitude of each tribe in Medina. Medina, as is well known, is a pluralist, multiethnic, cultural and ultireligious urban society. For a long time living in the city the Aus and Khadraj tribes, who had long been in the arena of hostility, Jews and Christians who lived in ghettos in physical boundaries, grouped in high fences to form their own villages.

In this discussion of Islamic pluralism, the Medina Charter is historical evidence that from the very beginning of the Holy Prophet, his intention was to build a truly inclusive and pluralist cosmopolitan society. This charter became the ideal foundation in building Medina and juridical evidence if he maintained the existence of other religions. He also describes the spirit of living together in plurality, the willingness to live in peace bound by mutual commitment in an agreement to defend each other.

From the above facts, a German sociologist named Robert N. Bellah mentioned that the constitution formulated by the Prophet Muhammad was a truly modern constitution which was not only for its time at that time, but also for space and time today, in modern times. This fact, added Bellah, occasionally is not an ideological fabrication that is unhistorical, but historical (Bellah, 2000).

However, it really requires historical evidence and facts that show, is it true that the early Islamic society was a modern society that was pluralist, inclusive and optimizing the participation of all citizens? Sociologically, that in the leadership of the Prophet who was later passed on by the four caliphs. In pluralist Medina the so-called race riot or racial riot never happened again. Before Islam, there were frequent occurrences where Medina was previously a city where racial conflicts were occurring. The four ethnic and religious groups then side by side with the Muslims, bound together in a sense of responsibility to maintain security together. In pluralist Medina there were never any racial riots. Before Islam, there were frequent occurrences where Medina was previously a city where racial conflicts were occurring. The four ethnic and religious groups then side by side with the Muslims, bound together in a sense of responsibility to maintain security together (Akkas \& Noer, 2000).

The betrayal of the Jews actually saddened the Prophet Muhammad and created a serious dilemma for him, an esoteric phenomenon that often escapes the observations of observers of the history of the Prophet, how the Holy Prophet, on the one hand, often taught his people to accept Jews as spiritual neighbors of tradition, the same religion, namely Ibrahim Religions but on the one hand in fact the Jews of Medina opposed the Prophet. Khaibar Jews, for example, a prosperous phase, assisted ten thousand troops for the Meccans in invading Medina. Overcoming this psychological dilemma, the prophet drew the conclusion that among the Jews there were two different groups, namely the sincere and the untrustworthy. So what was sternly acted upon by the Prophet and the Muslims as a logical consequence of the violation of the Medina constitution were those from the second group. As a result, two Jewish tribes, namely the Qaynuqa and Nadzir tribes, were exiled from Medina (Coward, 1989).

One of the other events that shows the implementation of pluralism is when the Prophet had a guest of a Naajran Christian delegation, then they were placed in friends' houses for several days and there was interfaith dialogue between them. And one day they said goodbye to the Prophet to leave the Nabawi mosque on the grounds that they would perform a service but, what the Prophet answered, history observers would be surprised because the Prophet forbade leaving the Nabawi mosque and invited the group to perform services at the Nabawi mosque. This event is recounted in the history of Islam in the book Sirah Ibn Ishaq $(85-151 \mathrm{H})$.

\section{Conclusion}

Observing pluralism with a normative and historical approach to Islam, and all the practical consequences thereof, provides a description that accepting religious pluralism is not only part of a humanitarian task but also a dimension of Muslimism and a religious duty that has divine values at the same time. Meanwhile, historically, Islam has been in the midst of social and pluralistic conditions since its inception, so that in its development it has become the religion that most appreciates the values of 
plurality of religious pluralism. Thus, Muslims have references that can be applied in the context of modern life, especially for pluralistic religious life in Indonesia, both from the Qur'anic texts and historical experiences. So that they should become moderate people [QS. Al Baqarah (2): 143], who no longer feels a dilemma if in his life he has to intersect with other religions, should instead be made a life partner in facing humanitarian problems.

\section{References}

Abdullah, M. Amin. 1999. "Studi Agama dan Normatifikasi atau Historisitas?” Yogyakarta: Pustaka Pelajar.

Akkas, M. Amin., and Hasan M Noer (eds). 2000. "Kemampuan Spititual Masyarakat Modern: Respon dan Transpormasi Nilai-nilai Islam Menuju Masyarakat Madani.” Jakarta: Media Citra,

Ali, H.A. Mukti. 1998. “Agama dan Pengumulan Masyarakat Modern.” Yogyakarta: Tiara Wacana Yogya.

Al-Maududi., and Abu A’la. 1995. “Al-Khilafah wa Al Mulk”, translated by Muhammad Al Baqir.” Bandung: Mizan.

Al-Qur'an Al-Karim

Asy’Arief, Musa. 2002. "Dialektika Agama untuk Pembebasan Spiritual.” Yogyakarta: Lesfi.

Bellah, Robert N. 2000. “Beyond Believe: Menemukan Kembali Agama (Esei-Esei tentang Agama di Dunia Modern”. Jakarta: Paramadina.

Coward, Harold. 1989. "Pluralisme: Tantangan Bagi Agama-Agama," translated by Tim Penerjemah. Yogyakarta: Aknisius.

Djam’annuri. 2002. "Islam dan Pluralisme Agama." Esensia 1(1): 4-5.

Engineer, Asghar Ali. 1993. "Islam dan Pembebasan,” translated by Hairus Salim HS. Yogyakarta: LKIS.

Hidayat, Komaruddin. 2002. "Indonesia Adalah Rumah Kita.” Suara Mubammadiyah 18: 87, September, 16-30.

Hidayat, Komaruddin., and Ahmad Gaus AF (eds). 1999. "Passing Over: Melintas Batas Agama.” Jakarta: Gramedia.

Kung, Hans. 1998. "Sebuah Model Dialog Kristen-Islam." Jurnal Pemikiran Islam Paramida 1(1).

Ma’arif, Ahmad Syafi'i. 1985. “Al-Qur’an, Realitas Sosial dan Simbol Sejarah (Sebuah Refleksi).” Bandung: Penerbit Pustaka.

Madjid, Nurcholis. 2002. "Islam Agama Peradaban.” Jakarta: Paramadina.

-----. 1992. "Islam Doktrin dan Peradaban.” Jakarta: PT. Temprint.

2005. "Islam Doktrin dan Peradaban Sebuah Telaah Kritis Tentang Masalah Keimanan, Kemanusiaan, dan Kemoderenan.” Jakarta: Paramadina.

Ridwan, M. Deden. 1999. "Membangun Teologi Kerukunan Islam Inklusif Menuju Sikap Terbuka dalam Beragama." Bandung: Mizan.

Shihab, M. Qurash. 1998. “Membumikan Al-Qur’an.” Bandung: Mirzan. 